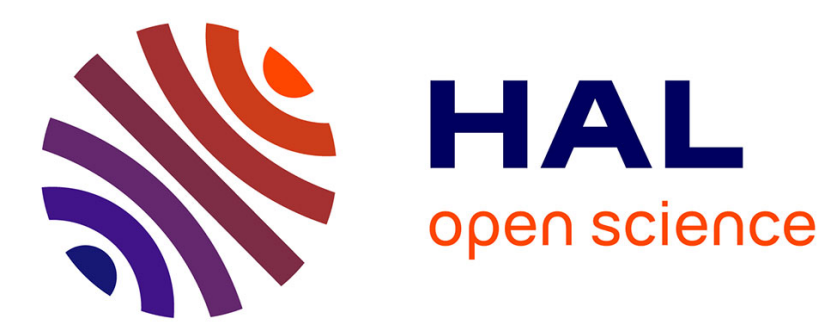

\title{
Influence of school environment on adolescents' creative potential, motivation and well-being
}

Maud Besançon, Fabien Fenouillet, Rebecca Shankland

\section{To cite this version:}

Maud Besançon, Fabien Fenouillet, Rebecca Shankland. Influence of school environment on adolescents' creative potential, motivation and well-being. Learning and Individual Differences, 2015, 43, pp.178 - 184. 10.1016/j.lindif.2015.08.029 . hal-01392503

\section{HAL Id: hal-01392503 \\ https://hal.parisnanterre.fr/hal-01392503}

Submitted on 9 Nov 2016

HAL is a multi-disciplinary open access archive for the deposit and dissemination of scientific research documents, whether they are published or not. The documents may come from teaching and research institutions in France or abroad, or from public or private research centers.
L'archive ouverte pluridisciplinaire HAL, est destinée au dépôt et à la diffusion de documents scientifiques de niveau recherche, publiés ou non, émanant des établissements d'enseignement et de recherche français ou étrangers, des laboratoires publics ou privés. 

10

Influence of school environment on adolescents' creative potential, motivation and wellbeing

\author{
Maud Besançon, Fabien Fenouillet, Rebecca Shankland
}

\begin{abstract}
9 It is increasingly acknowledged that creativity has become essential in daily life. Each
Abstract individual has the potential to be creative and the level of creativity actualization results from different factors that can be cognitive, conative and environmental. In particular, educational methods may impact creativity directly or indirectly through motivation and well-being. We hypothesized that the type of pedagogy influences levels of creativity, motivation and wellbeing. Furthermore, we hypothesized that creativity was linked to motivation and well-being. This study was conducted on 131 French adolescents attending a Waldorf school (alternative educational method) or a traditional school. Our results highlight differences in well-being and type of motivation when comparing both educational methods. Moreover, our results showed significant correlations between the different types of motivation and creativity scores.
\end{abstract}

Key words: educational methods; creativity; motivation; well-being; adolescents. 
Influence of school environment on adolescents' creative potential, motivation and wellbeing

\section{Introduction}

The rapid evolution of society obliges individuals to adapt constantly. Flexibility and creativity give the possibility to cope with the numerous changes people may have to face during their lives. Creativity is considered to be a necessary component of the problemsolving process (e.g., Mumford, Mobley, Uhlman, Reiter-Palmon \& Doares, 1991), and creative ideation develops greater flexibility (e.g., Runco, 1986), hence fostering well-being (e.g., Carson, Bittner, Cameron, Brown \& Meyer, 1994). Creativity has not only been described as a reaction to changes and as means of coping with it (Shaw \& Runco, 1994), but it has also been conceptualized as contributing to social and societal advances (Paulus \& Nijstad, 2003).

The ability to cope with new situations can thus be acquired through the development of autonomy, self-confidence, motivation and creativity (Carson, et al., 1994; Deci \& Ryan, 2000; Russ, Robins, \& Christiano, 1999; Shankland, Genolini, Riou França, Guelfi, \& Ionescu, 2010). All the above factors may be enhanced or hindered by the individual's immediate environment, in particular by the family (Dusek \& Danko, 1994; Kliewer \& Lewis, 1995; McIntyre \& Dusek, 1995; Ruchkin, Eisemann, \& Hagglof, 1999) and educational settings (Lillard \& Else-Quest, 2006; Mellou, 1996; Ogletree, 2000; Shankland, Riou França, Genolini, Guelfi, \& Ionescu, 2009). Mellou (1996) suggests that creativity may be nurtured through specific educational settings in three respects: the creative environment (material, classrooms...), creative programs and creative teachers or ways of teaching. These characteristics appear to be particularly present in alternative educational systems such as Montessori and Waldorf schools (e.g., Rose, Jolley, \& Charman, 2012; Murdock, 2003; Shankland, 2008).

The term creativity is used in this article as the ability to produce novel, original work that fits within particular task or domain constraints (Amabile, 1996; Gardner, 1996; Lubart, Mouchiroud, Tordjman, \& Zenasni, 2003; Ochse, 1990; Runco, \& Jaeger, 2012; Sternberg, \& Lubart, 1995). According to Sternberg and Lubart (1995), creativity is a cognitive aptitude which requires a confluence of three distinct and interrelated resources: cognitive factors 
(such as intelligence, knowledge), conative factors (such as personality, motivation, emotion) and environmental context. According to Snow (1994), levels of ability development and patterns of ability differentiation may result from different types of educational systems. However, each individual's learning history is also unique because individuals perceive situations differently according to their own background and interests. Thus, children's creative performances can be influenced by their conative aptitude, by their learning environment, and by the interaction between these two variables. The learning environment may have an impact on creative performances through explicit creativity development, for example by enhancing pretend play and role play in children according to their age (e.g., Russ et al., 1999) and by scheduling arts classes - as it can be observed in Waldorf schools (Rose, et al., 2012). Schools may also impact creativity indirectly through intrinsic motivation (Rathunde \& Csikszentmihalyi, 2005) and well-being enhancement (Fredrickson, 2001).

\subsection{Educational methods and creativity}

The French traditional educational system is based on norms and rules that allow the class to remain as calm and structured as possible. Therefore, autonomy and risk taking are not emphasized, and pupils often remain passive. Memorization and theory applications are more practiced than integration or active thinking. Generally, teachers give exercises, which support the development of convergent thinking. There is usually one single right answer to the problem presented, leaving little room for divergent thinking. Moreover, creative thinking is rarely solicited except in arts classes. In addition, students are often in competition with one another. Therefore they cannot develop perseverance and intrinsic motivation, which are two important components of creative performances.

Alternative educational practices based on Freinet, Montessori or Waldorf pedagogical methods appear to be characterized by: (1) autonomy development, (2) active participation in knowledge and skills acquisition and integration (not only memorization), (3) development of intrinsic motivation through activity choices (students may choose specific projects they wish to work on), and reduced competition (absence of marks, cooperation...; Lillard \& ElseQuest, 2006). According to Deci and Ryan's model (1985), autonomy-supportive and competence-focused educational methods meet students' fundamental psychological needs feelings of autonomy, competence and relatedness - thereby increasing intrinsic motivation and well-being (Ryan \& Deci, 2001). Through these pedagogical methods, both convergent and divergent thinking may be used, and learning is aimed at developing autonomy through 
the acquisition of skills and the development of psychosocial competencies rather than being mainly aimed at acquisition of knowledge (Kendal, 1992; Shankland, et al., 2009; Shankland, et al., 2010). Creative thinking is also particularly solicited through artistic activities - mainly in Waldorf (Steiner) schools - such as painting, modeling, sculpting and theatre.

During the latter of the 20th century, several studies compaired children's performances in traditional and in alternative educational systems. Horwitz (1979) conducted a literature review from the 1930s to the late 1970s. Globally, children who were exposed to alternative educational methods showed less cognitive rigidity, more nuanced and imaginative thinking; they took more initiatives, were more open, and less conventional. Nevertheless, children exposed to alternative education outperformed those in traditional classes.

Thomas and Berk (1981) conducted a literature review concerning the effects of different school environments on children's creativity, which also yielded inconclusive results. Their hypothesis was that the environment that best supports the development of creative performance is an intermediate one, neither too structured, nor too open or flexible. Their results highlighted a complex relation for the development of creativity, which is influenced by gender, type of educational system, and creativity type (verbal or figural). In particular, they found that (1) an intermediate environment best promoted creativity, and (2) that in general, boys were more creative than girls.

Ogletree (2000), using Torrance's creativity tests (1976), also compared Waldorf and classical schools students' productions. Waldorf schools students showed greater creativity than traditional schools students (cited by Rose, et al., 2012). These results may also be explained by the diversity of artistic classes proposed in Waldorf schools and autonomous creative exercises carried out by the students themselves at home (Shankland, 2008). For example, based on the classes given by the teachers, students have to create their own folder composed of the class contents, adding information they have looked up, and decorated by drawings aiming at illustrating the lesson or simply aiming at making their folder more agreeable to read. The higher levels of creativity may also be explained by the fact that in these schools, parents are strongly recommended to restrict television use at home. As the number of hours watching television is correlated to reduced creativity (Christakis \& Zimmerman, 2006), this constitutes a potential creativity factor in Waldorf students.

Another study comparing Montessori, Waldorf and classical school students (Cox \& Rowlands, 2000) underlined that Waldorf students productions were more accurate (proportions, perspective), detailed and also imaginative than those of other pupils. Where differences were found between classical school and Montessori pupils, the Montessori 
children tended to do better than the others. More recently, Besançon and Lubart (2008) also studied the influence of educational methods on the development of children's creativity. Their results indicated that, in general, children attending alternative education systems (Montessori and Freinet in that study) obtained higher performances than children attending traditional schools. In what concerns the positive influence of alternative educational methods on creative development from year 1 to year 2, the results show that Montessori curriculum was associated with an overall increase in creativity, for all children whatever their initial creative ability levels. However, this was not observed for children in Freinet classes. This difference could be explained by the fact that the teaching staff varied in the schools in which some teachers used Freinet pedagogical practices, whereas other teachers only used classical methods. Thus, some children in year 2 had a teacher who used traditional methods. These variations across the two years of the study support the hypothesis concerning the influence of educational methods on creativity development.

\subsection{Motivation}

Little use is made in alternative schools of marks which would operate as rewards or punishments for students (Shankland et al., 2010). Hence this type of education should lead to higher levels of intrinsic motivation (Deci, Koestner \& Ryan, 1999, 2001). Furthermore, Amabile (1982) showed that the use of rewards has a negative impact on child creativity. Meta-analyses also underlined that any type of reward and external incitation such as school assessments lead to reduced intrinsic motivation even for an activity considered by the students as interesting in the first place (Cameron \& Pierce; 1994; Deci et al., 1999, 2001). As opposed to these types of educational methods, alternative schools support student autonomy and social relationships which enhance student engagement in school activities as they act upon factors which have a positive impact on intrinsic motivation (Deci \& Ryan, 2000; Furrer \& Skinner, 2003; Ryan, Siller, \& Lynch, 1994). Enhancing intrinsic motivation is all the more important as extrinsic motivation reduces creativity (Amabile, 1988; Cooper \& Jayatilaka, 2006), while intrinsic motivation enhances creative performances (Jesus, Rus, Lens, \& Imaginário, 2013). By focalizing individuals on activity results rather than on the activity itself - as does intrinsic motivation - extrinsic motivation may lead to reduced cognitive flexibility which encourages individuals to use specific algorithms which have proved to be efficacious in past experiences rather than to test more innovative solutions (Cooper \& Jayatilaka, 2006). 
159

160

161

162

163

164

165

166

167

168

169

170

171

172

173

174

175

176

177

178

179

180

181

182

183

184

185

186

187

188

189

190

\subsection{Well-being}

Alternative educational settings highlight the importance of student well-being at school. Since the definition of Subjective Well-Being (SWB) given by Diener in 1984, many research studies have been carried out on this subject. SWB is referred to as the experience of high levels of positive emotions, low levels of negative emotions, and a high level of satisfaction with life. In line with research studies on the impact of childrearing on well-being (Dusek \& Danko, 1994; McIntyre \& Dusek, 1995), researchers have suggested that alternative schools such as Steiner and Montessori show a similar pattern of education involving relatively high levels of responsiveness, as well as a high demand for age-appropriate behavior (Lillard \& Else-Quest, 2006; Shankland et al., 2009). The hypothesis is thus made that these schools generate greater levels of SWB, which in turn should lead to higher creativity performances as suggested by a growing body of research on the links between positive affect and creativity (e.g., Amabile, Barsade, Mueller, \& Staw, 2005; Hirt, Melton, McDonald, \& Harackiewicz, 1996; Isen, Daubman, \& Nowicki, 1987). Fredrickson's “Broaden and Build model” (2001) suggests that positive emotions broaden the momentary action and thoughts repertory (e.g., Fredrickson \& Branigan, 2005), leading to higher levels of creativity and problem solving (as initially highlighted by Isen's studies, e.g., Isen, 1999; Isen, Daubman \& Nowicki, 1987). These competencies constitute new strengths, thereby building sustainable resources to cope with adversity (e.g., Fredrickson, Mancuso, Branigan, \& Tugade, 2000).

Since the initial work carried out by Isen and colleagues, there has been a growing interest in the link between positive emotions and creativity (for a meta-analysis see Davis, 2009). Isen, and colleagues (1987) showed that positive emotion induction improved creative performances. They originally explained this phenomenon through greater attention towards the task presented which would enhance the perception of details that could generally be ignored. They also argued that positive emotions would facilitate access to positive memories which are assumed to be more numerous than negative ones. A decade later, a neurocognitive model of positive emotions suggested that creative problem solving is improved, in part because of increased dopamine release in the anterior cingulate which enhances cognitive flexibility and facilitates the process of selection among various cognitive perspectives (Ashby, Isen, \& Turken, 1999). Research in this field continues to explore the links between positive affect and creativity. A recent study carried out by Masmoudi and Charaf (2013) appears to confirm this assumption. They presented a creative task with positive or negative 
191 valance words or with neutral ones and measured creative performances comparing these 192 three groups. The results indicate that positive words generated greater verbal fluency, 193 flexibility and originality.

194 With time, the models conceptualized to understand the relationship between emotions and creativity have become more complex and differentially explain the role of emotions on various creativity facets according to valance, arousal and intensity (De Dreu, Baas, \&

197 Nijstad, 2008; Kaufman \& Vosbung, 2002; Lin, Tsai, Lin, \& Chen, 2014; To, Fisher, 198 Ashkanasy, \& Rowe, 2012; Tsai, Lin, \& Lin, 2013). Indeed, emotions appear to influence the 199 different creative performances through distinct mechanisms. For example, Lin and colleagues (2014) showed that positive emotions enhanced creative performances either through cognitive flexibility (which totally mediated the relationship between positive emotional states and insight problem solving), while divergent thinking was rather associated with arousal levels. However, positive emotions remain central to these models, and ways of enhancing positive emotions in students have been tested since the early developments of positive psychology at school (see in particular publications on the Penn Resiliency Program; for a meta-analysis of its effects, see Brunwasser, Gillham, \& Kim, 2009). Although these research studies focused on positive moods or states - most frequently induced (Kaufman \& Beghetto, 2009) - rather than on general well-being, some studies have shown that happier students are more creative (e.g., Cacha, 1976). In the same way, happy workers appear to be more creative (Yuan, 2015).

212 Even though the benefits of creativity on intrinsic motivation and cognitive tasks have been documented (see Amabile, 1996), formal creativity or arts classes are often considered as less relevant to education or as mainly extra-curricular activities (Aljughaiman \& Mowrer215 Reynolds, 2005). Contrary to this belief, a survey underlined that in Steiner schools, teachers considered arts and creativity as a central component of all classes (Woods, Ashley, \& Woods, 2005). Most of these teachers (95\%) also highlighted that artistic and creative skills were an essential feature of Waldorf school teachers. As other studies carried out on alternative schools such as Montessori have also underlined greater levels of intrinsic motivation (Rathunde \& Csikszentmihalyi, 2005), and studies on former alternative school students highlighted higher levels of SWB (Shankland et al., 2010) - lower levels of anxiety and depression symptoms and higher levels of satisfaction with life - it was assumed here that 


\subsection{Present Study}

226 In the current study, we examined the relationship between learning environment and students' creative performances, as well as its correlations with motivation and well-being. Based on the literature, we first tested the hypothesis according to which the type of pedagogy influenced the level of creativity, motivation and well-being. Secondly, we tested whether (1) creativity related to motivation, and (2) how creativity related to well-being.

\section{Method}

\subsection{Participants}

234 The data analyzed in this study was obtained from a sample of 131 French adolescents (48.9\% 235 boys, $51.1 \%$ girls; mean age $=12.74, \mathrm{SD}=0.97)$ : 41 from a Waldorf school, alternative 236 education; 90 from a traditional school. Each sample was recruited from schools in the 237 vicinities of Paris.

238 Authorizations were first sought from the headmaster and teachers and then the students' 239 parents. Only children whose parents had agreed to participate were included in the results of 240 this research.

\subsection{Material}

2.2.1. Creativity measure - Evaluation of Potential of Creativity (EPoC, Lubart, Besançon \& Barbot, 2011)

245 The authors considered creativity as a multifaceted, domain-specific construct, so instruments to measure creativity may vary as a function of the domain-component aimed at being measured. Moreover, it is possible to categorize the numerous micro-processes involve in creative potential into two main sets, called divergent-exploratory processes, and convergentintegrative processes. According to this point of view, these tests battery measures two key creative thinking-process clusters (divergent-exploratory and convergent-integrative) in verbal-literary and graphic domains (with forthcoming extensions in other domains such as social, scientific and musical domains, see Table 1). In the Divergent-Exploratory thinking tasks for graphic domain (DG index), test-takers must generate as many drawings as possible using a simple abstract shape (DG1 - Abstract Stimulus) or a familiar object (DG2 - Concrete

255 Stimulus) as starting point, in a limited time (10 minutes). Similarly, divergent-exploratory 256 thinking tasks in the verbal domain (DV index) consist of generating either multiple simple 257 story-endings in response to a unique story-beginning (DV1 - Story Endings), or multiple 
story-beginnings in response to a unique story-ending (DV2 - Story Beginnings), in 10

259 minutes. In contrast, the convergent-integrative tasks in the graphic domain (IG index) engage test-takers to produce a complete, original drawing, using at least four out of eight abstract shapes (IG1 - Abstract Stimuli) or familiar objects (IG2 - Concrete Stimuli) provided as a basis for their composition (within the 15 minutes allowed for these tasks). Similarly, in the convergent-integrative tasks applied to the literary-verbal domain, test takers have to produce a complete story either based on a provided story title (IV1 - Story Title), or on the integration of imposed fictional characters (IV2 - Story Characters).

Insert Table 1 about here

271 Concerning Divergent-Exploratory thinking tasks, several studies show that fluidity is strongly linked to the originality of ideas. Lubart et al. (2003) have shown that the more original ideas tend to be produced later during divergent thinking. Hence Divergent-

274 Exploratory thinking tasks are norm-referenced (comparison of an individual's number of relevant responses generated in response to the task, in comparison to her or his reference group), while Convergent-integrative tasks are assessed using the Consensual Assessment 277 Technique (CAT, Amabile, 1982), rated by at least three independent and qualified judges 278 (that is, the creative productions are assessed with regard to a set of defined rubrics ${ }^{1}$, ranging from "1-low creativity" to "7-high creativity"). Three raters $\left(\mathrm{M}_{\mathrm{age}}=38.9 ; \mathrm{SD}=4.7\right)$ assessed story creativity and drawing creativity. Judges were university professionals or $\mathrm{PhD}$ students who work regularly in the field of creativity. The inter-rater reliability is good $(\alpha>.80)$ for the four integrative tasks $(\alpha \mathrm{IG} 1=.83 ; \alpha \mathrm{IG} 2=.85 ; \alpha \mathrm{IV} 1=.91$ and $\alpha \mathrm{IV} 2=.90)$.

${ }^{1}$ For example, score 1 in the integrative task graphic corresponds to the rubric "very poor, total lack of idea" whereas score 7 corresponds to "a very original idea that encompassed all elements". For the verbal integrative task, score 2 means "a story which includes banal or traditional ideas" and score 7 corresponds to an "original story, well built with many details". 


\subsubsection{Motivation measures}

285 We used an adapted version of the 20 items Academic Motivation Scale (Vallerand, Blais, 286 Brière, \& Pelletier, 1989). The adaptation consisted of adapting items to be more comprehensive to early teenage students and we measured only one form of intrinsic motivation out of three. Participants had to fill out the questionnaire by answering on a 5 point Likert scale ranging from: "Totally disagree" to "Totally agree". This scale enables one to measure: intrinsic motivation for knowledge $(\alpha=.84$, eg. Because I experience pleasure and satisfaction while learning new things), external regulation extrinsic motivation $(\alpha=.75$, eg.

292 Because I want to have good life later on), introjected regulation extrinsic motivation $(\alpha=.82$, eg. Because of the fact that when I succeed in school I feel important), identified regulation extrinsic motivation $(\alpha=.74$, eg. Because this will help me make a better choice regarding my career orientation), and amotivation ( $\alpha=.77$, eg. Honestly, I don't know; I really feel that I am wasting my time in school). We only used intrinsic motivation because in the present study the other types of intrinsic motivation did not yield more information on the selfdetermination continuum contrary to the types of extrinsic motivation.

\subsubsection{Well-being measures}

301 We used the 5 items Satisfaction With Life Scale (Diener, Emmons, Larsen, \& Griffin, 1985) 302 which is one of the most cited subjective well-being scale in research studies. The aim of integrating this scale was to have a global measure of individual subjective well-being through the assessment of general life satisfaction. The French validation was carried out by Blais, Vallerand, Pelletier, and Brière (1989). Participants answered each item (eg. In most ways my life is close to my ideal) on a seven-point Likert scale ranging from: "Totally disagree" to "Totally agree". Internal consistency of the scale was satisfactory $(\alpha=.86)$.

A second well-being measure was used: the 7 items Students' Life Satisfaction Scale (Huebner, 1991). This scale aims at assessing student general satisfaction (eg. My life is better than most kids). Participants rated their satisfaction on a six-point Likert scale ranging from:

311 "Totally disagree" to "Totally agree". Internal consistency of the scale was satisfactory $312(\alpha=.83)$.

\subsection{Procedure}

315 Students were seen in three successive collective sessions, per class, and each session (around 31645 minutes each) was separated by one week. The battery EPoC was administered in two 
sessions, each of which included four tasks (DG1, DV1, IG1, IV1 in the first session, and

318 DG2, DV2, IG2, IV2 in the second session). During the last session, students completed motivation and well-being questionnaires.

\subsection{Data Analyses}

322 For the following statistical analyses, missing data (less than 5\%) were imputed in order to 323 complete the scale by using the SPSS (version 22) expectation-maximization procedure. This 324 procedure is considered as superior to other methods (Allison, 2002) such as removing 325 participants with missing data (list-wise deletion).

\section{Results}

\subsection{Preliminary analyses}

The results show that Waldorf students were slightly older $(\mathrm{M}=12.83, \mathrm{SD}=0.66)$ than traditional school students $(\mathrm{M}=12.24, \mathrm{SD}=.60 ; \mathrm{t}(129)=13.70, \mathrm{p}<.001)$. We will therefore control for age in further analyses.

332 In order to determine the number of factors to be extracted we used the SPSS procedure 333 developed by O'Connor (2000) using parallel analyses. These analyses are based on Monte 334 Carlo simulations which enable the number of factors which may be extracted from the set of data to be determined while minimizing data loss and without enhancing random data. This method consists of generating a hundred matrices of random numbers of similar size in terms of participants and factors as the actual sample. The Eigenvalue of each factor extracted from the matrices were used to calculate the mean and standard deviation of the distribution randomly selected among the matrices identical to the set of data considered. The value corresponding to the $95^{\text {th }}$ percentile was used as a threshold beneath which the factors are considered as potentially randomly extracted (Cota, Longman, Holden, Fekken, \& Xinaris, 1993; Turner, 1998). As shown in Table 2, the parallel analyses method enables to select only two factors, as the value of the third factor (1.01) is inferior to the $95^{\text {th }}$ percentile (1.18). 
349 We selected an oblimin rotation because we hypothesized that the factors were correlated.

350 The results of the principal component factor analysis with oblimin rotation explained $46.30 \%$ 351 of the total variance. The first factor explained $29.82 \%$ of the total variance. After rotation, 352 the four integrative thinking items of this factor (IT) presented loadings superior to .40 while 353 the divergent thinking items (DT) all presented loadings inferior to .30. Conversely, on the 354 second factor which explained $16.48 \%$ of the variance, after rotation the four DT items 355 presented loadings superior to .40 whereas the IT items all presented loadings inferior to .30 .

\subsection{Main results}

\subsubsection{Creativity}

For the variance analyses we carried out a MANOVA because the dependent variables were correlated and age difference between the two groups was significant and thus included as a control variable. There were no significant differences between Waldorf $(\mathrm{M}=0.14, \mathrm{SD}=0.60)$ and traditional schools $(\mathrm{M}=-.09, \mathrm{SD}=0.73)$ regarding Divergent Thinking $(\mathrm{F}[1,128]=0.22$, $\mathrm{p}>.05$ ) and Integrative Thinking (Waldorf: $\mathrm{M}=3.98, \mathrm{SD}=0.71$; traditional schools: $\mathrm{M}=3.43$, $\left.\mathrm{SD}=0.82 ; \mathrm{F}[1,128]=2.18, \mathrm{p}>.05, \eta^{2}=.11\right)$.

\subsubsection{Self-determined motivations}

367 The results show a significant difference between the three types of extrinsic regulations 368 (external, introjected and identified) and the type of educational method, as shown in Table 3. 369 Students from the traditional educational system showed more extrinsic motivation than 370 Waldorf school students. However, no significant difference appeared for intrinsic motivation scores $(F[1,107]=0.00, n s)$, external motivation $(F[1,107]=0.88$, ns $)$ or amotivation scores

$372(\mathrm{~F}[1,107]=0.20, \mathrm{~ns})$. 
382 As shown in Table 4, significant correlations appear between the different types of 383 motivations and the creativity scores: negative correlations between extrinsic regulations and 384 integrative thinking scores, but the greater the degree of self-determination of the motivation 385 type the weaker the correlation: for the total sample, a negative correlation is observed for IT 386 and external regulation $(\mathrm{r}=-.27, \mathrm{p}<.01)$, while the weakest negative correlation is between IT 387 and introjected regulation $(\mathrm{r}=-.22, \mathrm{p}<.05)$ but no relation is observed with identified regulation $388(\mathrm{r}=-.14, \mathrm{~ns})$. However, this effect of the type of extrinsic motivation is mainly observed for the 389 Waldorf students. For this subsample, the relationship between IT and the different types of regulations ranges from a .50 correlation $(\mathrm{p}<.01)$ to a -.39 correlation $(\mathrm{p}<.05)$, while in the traditional school subsample there was no significant correlation between these variables. In

392 the traditional school subsample, the significant correlations concern IT and amotivation 393 scores $(r=-.29, \mathrm{p}<.01)$, and DT and introjected regulation $(\mathrm{r}=-.33, \mathrm{p}<.01)$. The correlational 394 patterns between motivation and creativity are thus different according to the educational 395 methods under study.

\subsubsection{Well-being}

398 No significant difference between Waldorf $(\mathrm{M}=4.76, \mathrm{SD}=1.14)$ and traditional school $399(\mathrm{M}=4.85, \mathrm{SD}=1.48)$ students was observed for general satisfaction with life $(\mathrm{F}[1,128]=0.12$, $400 \mathrm{~ns})$, but there were significant differences between Waldorf $(\mathrm{M}=4.36, \mathrm{SD}=0.90)$ and 401 traditional school $(\mathrm{M}=4.18, \mathrm{SD}=1.19)$ student life satisfaction scores $\mathrm{F}[1,128]=8.20, \mathrm{p}<.01)$. 402 When analyzing the Waldorf school subsample data, a negative correlation appears between 403 well-being measures and Integrative Thinking: SWLS and IT $(r=-.48, p<.001)$, and SLSS and 404 IT $(\mathrm{r}=-.41, \mathrm{p}<.001)$. The results suggest that the students who scored high on IT reported 405 lower levels of life satisfaction. No correlation was shown for the traditional school 406 subsample in what concerns the link between well-being and creativity. 


\section{Discussion}

414 Two main set of hypotheses were examined. The first one concerned the relationship between 415 pedagogical methods and creativity, motivation and well-being. Contrary to our expectations, 416 our results do not show an effect of the type of pedagogy on creative potential on Divergent or 417 Integrative Thinking. Several explanations can be put forward. First, the pedagogical methods 418 studied were different from the previous study carried out on this question (Waldorf for the 419 present study vs. Montessori and Freinet in the previous study). Second, the experimental 420 design was different: collective versus individual task completion. These differences should 421 be controlled in future research.

422 In what concerns motivation, our results show an effect of the type of school on extrinsic motivation: students from traditional school settings were more extrinsically motivated than students from the Waldorf school. These results are consistent with previous work (Deci et al., 1999, 2001). Regarding well-being, our results did not highlight any difference in general life satisfaction, but in student life satisfaction. This may be explained by the fact that general life satisfaction is influenced by other variables such as personality traits (DeNeve \& Cooper, 1998) and family relationships (e.g., Bendayan, Blanca, Fernández-Baena, Escobar, \& Victoria Trianes, 2013), whereas student life satisfaction is directly impacted by educational methods and systems (e.g., Shankland et al., 2010), and the way they influence teacherstudent relationships, type of motivation and general relationships between students at school. Our second set of hypotheses concerned the relationship between creativity and motivation on the one hand and creativity and well-being on the other hand. Our results highlighted a negative relationship between creativity and extrinsic motivation: the stronger the extrinsic motivation, the less creative the children were on integrative thinking tasks. A pedagogy focused on the development of individual potentialities generates less extrinsic motivation and hence does not diminish the potential of integrative thinking. This finding is congruent with previous work (Cooper \& Jayatilaka, 2006; Furrer \& Skinner, 2003; Ryan et al., 1994). However, contrary to our expectations, our results did not show any relationship between creativity and well-being, except for Waldorf school pupils with the opposite correlation to that hypothesized: the more creative the pupils were, the less satisfied they were with their current life. While only speculations can be proposed in the present case, we could hypothesize that well-being measures may generally be completed with the intent to communicate a good impression (social desirability). Therefore, the more the participant tries to correspond to an awaited standard, the less creative they may be. The social desirability bias could thus help us understand why greater creative performances in Waldorf students 
were correlated to lower levels of satisfaction with life. This bias is recurrently underlined in

448 various research fields. Almost half the studies reported in van de Mortel (2008) showed an 449 influence of social desirability on self-reported measures, and social desirability has been 450 highlighted as being potentially an even greater bias in positive psychology research (Osin, 451 2009), as such studies tackle desirable phenomena such as well-being and flourishing 452 (Seligman \& Csikszentmihalyi, 2000).

453 Hence, a first limitation of the present study is the absence of use of a social desirability scale. 454 A second important limitation concerns the fact that students were not randomly assigned to a 455 particular school setting. Therefore, it is not possible to determine whether the educational 456 method in itself leads to higher creative performances as other factors have not been 457 controlled for. A third limitation concerns the focus on a single alternative pedagogy 458 (Waldorf). Indeed, each alternative school has it specificities which may differently impact 459 creativity and well-being. Further research studies should therefore include various 460 pedagogical methods, such as Montessori, Freinet and Waldorf. Moreover, it would be 461 interesting to compare the results on the EPOC battery obtained by these adolescent groups 462 with a more consequent reference group and to verify the factorial structure of the test. A 463 further limitation is the lack of information about the time the students have spent in their 464 present school system, information which should be included in future research in order to 465 control for this variable when measuring impact on creative potential.

466 To conclude, the results obtained in the present research study highlight lower levels of 467 extrinsic motivation in Waldorf schools which is linked to higher divergent creativity scores. 468 Future research studies on well-being may want to use other types of measures which can be 469 considered as health promotion factors rather than current life satisfaction.

470 
Aljughaiman, A., \& Mowrer-Reynolds, E. (2005). Teachers' conceptions of creativity and creative students. The Journal of Creative Behavior, 39, 17-34.

Allison, P. (2002). Missing data. Thousand Oaks, CA: Sage Publications.Amabile, T. M. (1982). Children's artistic creativity: Detrimental effects of competition in a field setting. Personality and Social Psychology Bulletin, 8, 573-578.

Amabile, T. M. (1988). A model of creativity and innovation in organizations. In B. Staw \& L. L. Cummings (Eds.), Research in Organizational Behavior, 10, 123-167.

Amabile, T. M. (1996). Creativity in context: Update to "the social psychology of creativity".

$$
\text { Boulder, CO, US: Westview Press. }
$$

Ashby, F. G., Isen, A. M., \& Turken, A. U. (1999). A neuropsychological theory of positive 486 affect and its influence on cognition. Psychological Review, 106, 529-550.

Bendayan, R., Blanca, M. J., Fernández-Baena, J. F., Escobar, M., \& Victoria Trianes, M. (2013). New empirical evidence on the validity of the Satisfaction with Life Scale in early adolescents. European Journal of Psychological Assessment, 29, 36-43.

Besançon, M. \& Lubart, T. (2008). Differences in the development of creative competencies in children schooled in diverse learning environments. Learning and Individual Differences. Vol (18), 381-389.

Blais, M.R., Vallerand, R.J., Pelletier, L.G., \& Brière, N.M. (1989). L'Échelle de satisfaction de vie : Validation canadienne-française du "Satisfaction with Life Scale". Revue canadienne des sciences du comportement, 21, 210-223.

Brunwasser, S. M., Gillham, J. E., \& Kim, E. S. (2009). A meta-analytic review of the Penn resiliency program's effect on depressive symptoms. Journal of Consulting and Clinical Psychology, 77, 1042-1054

Cacha, F. B. (1976). Figural creativity, personality, and peer nominations of pre-adolescents. Gifted Child Quarterly, 20, 187-195.

Cameron, J., \& Pierce, W. D. (1994). Reinforcement, reward, and intrinsic motivation: A meta-analysis. Review of Educational Research, 64, 363-423.

Carson, D. K., Bittner, M. T., Cameron, B. R., Brown, D. M., \& Meyer, S. S. (1994). Creative thinking as a predictor of school-aged children's stress responses and coping abilities. Creativity Research Journal, 7, 145-158. 
Christakis, D., Zimmerman, F. J. (2006). Media as a public health issue. Archives of Pediatrics and Adolescent Medicine, 160, 445-446.

Cooper, R. B., \& Jayatilaka, B. (2006), Group creativity: The effects of extrinsic, intrinsic, and obligation motivations. Creativity Research Journal, 18, 2, 153-172.

Cotta, A. A., Longman, R. S., Holden, R. R., Fekken, G. C., \& Xinaris, S. (1993). Interpolating $95^{\text {th }}$ percentile eigenvalues from random data: An empirical example. Educational \& Psychological Measurement, 53, 585-596.

Cox, M. V., \& Rowlands, A. (2000). The effect of three different educational approaches on children's drawing ability: Steiner, Montessori and traditional. British Journal of Educational Psychology, 70, 485-503.

Davis, M. A. (2009). Understanding the relationship between mood and creativity: a metaanalysis. Organizational Behavior and Human Decision Processes, 108, 25-38.

De Dreu, C. K. W., Baas, M., \& Nijstad, B. A. (2008). Hedonic tone and activation in the mood-creativity link: Towards a dual pathway to creativity model. Journal of Personality and Social Psychology, 94, 739-756.

Deci, E. L., \& Ryan, R. M. (1985). Intrinsic motivation and self-determination in human behavior. New York: Plenum.

Deci, E. L., \& Ryan, R. M. (2000). The "what" and "why” of goal pursuits: Human needs and the self-determination of behavior. Psychological Inquiry, 11, 227-268.

Deci, E. L., Koestner, R., \& Ryan, R. M. (1999). The undermining effect is a reality after all-Extrinsic rewards, task interest, and self-determination: Reply to Eisenberger, Pierce, and Cameron (1999) and Lepper, Henderlong, and Gingras (1999). Psychological Bulletin, 125, 692-700.

Deci, E. L., Koestner, R., \& Ryan, R. M. (2001). Extrinsic rewards and intrinsic motivation in education: Reconsidered once again. Review of Educational Research, 71, 1-27.

DeNeve, K. M., \& Cooper, H. (1998).The happy personality: A meta-analysis of 137 personality traits and subjective well-being. Psychological Bulletin, 124, 197-229.

Diener, E. (1984). Subjective well-being. Psychological Bulletin, 95, 542-575.

Diener, E., Emmons, R. A., Larsen, R. J., \& Griffin, S. (1985). The satisfaction with life scale. Journal of Personality Assessment, 49, 71-75.

Dusek, J. B., \& Danko, M. (1994). Adolescent coping styles and perceptions of parental child rearing. Journal of Adolescent Research, 9, 412-426. 
Fredrickson, B. L. (2001). The role of positive emotions in positive psychology: The broadenand-build theory of positive emotions. American Psychologist. 56, 218-226.

539

540

Fredrickson, B. L., \& Branigan, C. (2005). Positive emotions broaden the scope of attention and thought-action repertoires. Cognition and Emotion, 19, 313-332.

Fredrickson, B. L., Mancuso, R. A., Branigan, C., \& Tugade, M. M. (2000). The undoing effect of positive emotions. Motivation and Emotion, 24, 237-258.

Furrer, C., \& Skinner, E. (2003). Sense of relatedness as a factor in children's academic engagement and performance. Journal of Educational Psychology, 95, 148-162.

Gardner, H. (1996). L'intelligence et l'école: La pensée de l'enfant et les visées de l'enseignement. Paris: Retz.

Horwitz, R. A. (1979). Psychological effects of the open classroom. Review of Educational Research, 49, 71-85.

Huebner, E. S. (1991). Correlates of life satisfaction in children. School Psychology Quarterly, 6, 103-111.

Isen, A. (1999). On the relationship between affect and creative problem solving. In S. Russ (Ed.), Affect, creative experience, and psychological adjustment (pp. 3-19). Philadelphia, PA: Taylor and Francis.

Isen, A. M., Daubman, K. A., \& Nowicki, G. P. (1987). Positive affect facilitates creative problem solving. Journal of Personality and Social Psychology, 56, 1122-1131.

Jesus, S. N., Rus, C., Lens, W., \& Imaginário, S. (2013). Creativity and intrinsic motivation: A meta-analysis of the studies between 1990-2010. Creativity Research Journal, 25, 8084.

Kaufman, J. C., \& Beghetto, R. A. (2009). Beyond big and little: The four c model of creativity. Review of General Psychology, 13, 1-12.

Kaufmann, G. \& Vosburg, S. (2002). The effects of mood on early and late idea production. Creativity Research Journal, 14, 317-330.

Kendall, S. (1992). The development of autonomy in children: An experiment of the Montessori educational model. Doctoral Thesis, Waldon University, Unites-States of America.

Kliewer, W., \& Lewis, H. (1995). Family influences on coping processes in children and adolescents with sickle cell disease. Journal of Pediatric Psychology, 20, 511-525.

Lillard, A., \& Else-Quest, N. (2006). Evaluating Montessori education. Science, 313, 18931894.

See Fig. 1 
Lin, W.-L., Tsai, P.-H., Lin, H.-Y., \& Chen, H.-C; (2014). How does emotion influence different creative performances? The mediating role of cognitive flexibility. Cognition and Emotion, 28, 834-844.

Lubart T.I., Besançon M, Barbot B. (2011). Evaluation du Potentiel Créatif. (EPoC). Paris, France : Editions Hogrefe.

Lubart, T., Mouchiroud, C., Todjman, S., \& Zenasni, F. (2003). Psychologie de la créativité. Cahors, France: Armand Colin.

Masmoudi, S., \& Charaf, I. (2013). Verbal creativity and emotional valence: "I become more creative when I see a positive word”. European Revue of Applied Psychology, 63, 219229

McIntyre, J. G., \& Dusek, J. B. (1995). Perceived parental rearing practices and styles of coping. Journal of Youth and Adolescence, 24, 499-509.

Mellou, E. (1996). Can creativity be nurtured in young children? Early Child Development and Care, 119, 119-30.

Mumford, M. D., Mobley, M. I., Uhlman, C. E., Reiter-Palmon, R., \& Doares, L. M. (1991). Process analytic models of creative capacities. Creative Research Journal, 4, 91-122.

Murdock, M. C. (2003). The effects of teaching programmes intended to stimulate creativity: A disciplinary view. Scandinavian Journal of Educational Research, 47, 339-57.

O'Connor, B. P. (2000). SPSS and SAS programs for determining the number of components using parallel analysis and Velicer's MAP test. Behavior Research Methods, Instrumentation, and Computers, 32, 396-402.

Ochse, R. (1990). Before the gates of excellence: The determinants of creative genius. NewYork: Cambridge University Press.

Ogletree, E. J. (2000). Creative thinking development of Waldorf school students. Trans Intelligence Magazine, 8, 1-6.

Osin, E. N. (2009). Social desirability in positive psychology: Bias or desirable sociality? In T. Freire (Ed.), Understanding Positive Life Research and Practice on Positive Psychology. Climepsi: Lisabon, Portugal, 407-428.

Paulus, P. B., \& Nijstad, B. A. (2003). Group creativity: Innovation through collaboration. New York: Oxford University Press.

Rathunde, K., \& Csikszentmihalyi, M. (2005). Middle school students' motivation and quality of experience: A comparison of Montessori and traditional school environments. American Journal of Education, 111, 341-371. 
604

605

606

607

608

609

610

611

612

613

614

615

616

617

618

619

620

621

622

623

624

625

626

627

628

629

630

631

632

633

634

635

636

637

Rose, S. E., Jolley, R. P., \& Charman, A. (2012). An investigation of the expressive and representational drawing development in National Curriculum, Steiner and Montessori schools. Psychology of Aesthetics, Creativity and the Arts, 6, 85-93.

Ryan, R. M., \& Deci, E. L. (2001). On happiness and human potentials: A review of research on hedonic and eudaimonic well-being. In S. Fiske (Ed), Annual review of psychology (Vol 52, pp. 141-166). Palo Alto, CA: Annual Reviews, Inc.

Ryan, R. M., Stiller, J. D., \& Lynch, J. H. (1994). Representations and relationships to teachers, parents, and friends as predictors of academic motivation and self-esteem. Journal of Early Adolescence, 14, 226-249.

Ruchkin, V. V., Eisemann, M., \& Hagglof, B. (1999). Coping styles in delinquent adolescents and controls: The role of personality and parental rearing. Journal of Youth and Adolescence, 28, 705-717.

Runco, M. A. (1986). Flexibility and originality in children's divergent thinking. Journal of Psychology, 120, 345-52.

Runco, M. A. \& Jaeger, G. J. (2012). The standard definition of creativity. Creativity Research Journal, 24, 92-96.

Russ, S. W., Robins, A. L., \& Christiano, B. A. (1999). Pretend Play: Longitudinal Prediction of Creativity and Affect in Fantasy in Children. Creativity Research Journal, 12, 129139.

Seligman, M. E. P., Csikszentmihalyi, M. (2000). Positive psychology: An introduction. American Psychologist, 35, 5-14.

Shankland, R. (2008). Développer les compétences psychosociales. Paris: L’Harmattan.

Shankland, R., Genolini, C., Riou França, L., Guelfi, J.-D., \& Ionescu, S. (2010). Student adjustment to higher education: The role of alternative educational pathways in coping with the demands of student life. Higher Education, 59, 353-366.

Shankland, R., Riou França, L., Genolini, C., Guelfi, J.-D., \& Ionescu, S. (2009). Preliminary study on the role of alternative educational pathways in promoting the use of problemfocused coping strategies. European Journal of Psychology of Education, 24, 499-512.

Shaw, M. P., \& Runco, M. A. (1994). Creativity and affect. Norwood, NJ: Ablex.

Snow, R. (1994). A Person-Situation Interaction Theory of Intelligence in Outline. In A. Demetriou, \& A. Efklides (Eds.), Intelligence, Mind, and Reasoning: Structure and Development (pp. 11-28). Amsterdam: Elveiser Science.

Sternberg, R. J., \& Lubart, T. I. (1995). Defying the crowd: Cultivating creativity in a culture of conformity. New York: Free Press. 
638 Thomas, N. G., \& Berk, L. E. (1981). Effects of school environments on the development of 639 young children's creativity. Child-Development, 52(4), 1153-1162.

640 To, M. L., Fisher, C. D., Ashkanasy, N. M., \& Rowe, P. A. (2012). Within-person 641 relationships between mood and creativity. Journal of Applied Psychology, 97, 599-612. 642 Torrance, E. P. (1976). Les tests de pensée créative. Paris: Les Editions du Centre de 643 Psychologie Appliquée.

644 Tsai, P.-H., Lin, W.-L., \& Lin, H.-Y. (2013). Right moods, right creativities: Differential 645 effects of emotional states on divergent thinking and insight problem solving. Bulletin 646 of Educational Psychology, 45, 19-38.

647 Turner, N. E. (1998). The effect of common variance and structure on random data 648 eigenvalues: Implications for the accuracy of parallel analysis. Educational \& 649 Psychological Measurement, 58, 541-568

650 Vallerand, R. J., Blais, M. R., Brière, N. M., \& Pelletier, L. G. (1989). Construction and 651 validation of the Motivation Toward Education Scale. Canadian Journal of Behavioural 652 Science, 21, 323-349.

653 Van de Mortel, T. F. (2008). Faking it: Social desirability response bias in self-report 654 research. Australian Journal of Advanced Nursing, 25, 40-48.

655 Woods, P., Ashley, M., \& Woods, G. (2005). Steiner Schools in England. University of the 656 West of England: Centre for Research in Education and Democracy. 


\section{Tables}

663 Table 1

664 EPoC Structured framework for tasks sampling

\section{Thinking Process}

\begin{tabular}{lcc}
\cline { 2 - 3 } Domain & Divergent-Exploratory & Convergent-Integrative \\
Graphic & DG1 - Abstract Stimulus & IG1 - Abstract Stimuli \\
& DG2 - Concrete Stimulus & IG2 - Concrete Stimuli \\
Verbal & DV1 - Story Endings & IV1 - Story Title \\
& DV2 - Story Beginnings & IV2 - Story Characters
\end{tabular}

665

666 
667

668 Table 2

669 Parallel analysis results

\begin{tabular}{llll}
\hline Factor & Eigenvalue & Mean & $95 \%$ \\
\hline 1 & 2.39 & 1.39 & 1.53 \\
2 & 1.32 & 1.23 & 1.32 \\
3 & 1.01 & 1.12 & 1.18 \\
\hline
\end{tabular}

670

671 
673 Table 3

674 Motivation types, well-being, descriptive and inferential statistical analyses according to the 675 group (with age as controlled variable)

\begin{tabular}{|c|c|c|c|c|c|c|}
\hline & & $\mathrm{n}$ & Mean & SD & $\mathrm{F}[1,128]$ & $\eta 2$ \\
\hline \multirow[t]{3}{*}{ Amotivation } & Waldorf & 41 & 1.74 & 0.90 & \multirow{3}{*}{0.00} & \multirow{3}{*}{0.00} \\
\hline & Traditional & 90 & 1.68 & 0.87 & & \\
\hline & Total & 131 & 1.70 & 0.88 & & \\
\hline \multirow{3}{*}{$\begin{array}{l}\text { EM } \\
\text { External }\end{array}$} & Waldorf & 41 & 3.75 & 1.14 & \multirow{3}{*}{0.88} & \multirow{3}{*}{0.01} \\
\hline & Traditional & 90 & 4.38 & 0.63 & & \\
\hline & Total & 131 & 4.19 & 0.87 & & \\
\hline \multirow{3}{*}{$\begin{array}{l}\text { EM } \\
\text { Introjected }\end{array}$} & Waldorf & 41 & 2.94 & 1.06 & \multirow{3}{*}{$6.26^{*}$} & \multirow{3}{*}{0.05} \\
\hline & Traditional & 90 & 3.76 & .99 & & \\
\hline & Total & 131 & 3.50 & 1.08 & & \\
\hline \multirow{3}{*}{$\begin{array}{l}\text { EM } \\
\text { Identified }\end{array}$} & Waldorf & 41 & 3.77 & .88 & \multirow{3}{*}{$5.79 *$} & \multirow{3}{*}{0.04} \\
\hline & Traditional & 90 & 4.34 & 0.70 & & \\
\hline & Total & 131 & 4.16 & 0.80 & & \\
\hline \multirow{3}{*}{$\begin{array}{l}\text { Intrinsic } \\
\text { Motivation }\end{array}$} & Waldorf & 41 & 3.47 & 0.87 & \multirow{3}{*}{0.20} & \multirow{3}{*}{0.00} \\
\hline & Traditional & 90 & 3.68 & 1.02 & & \\
\hline & Total & 131 & 3.62 & 0.98 & & \\
\hline \multirow{3}{*}{ SWLS } & Waldorf & 41 & 4.76 & 1.14 & \multirow{3}{*}{1.46} & \multirow{3}{*}{0.01} \\
\hline & Traditional & 90 & 4.85 & 1.48 & & \\
\hline & Total & 131 & 4.82 & 1.38 & & \\
\hline \multirow{3}{*}{ SLSS } & Waldorf & 41 & 4.36 & 0.90 & \multirow{3}{*}{$8.20 * *$} & \multirow{3}{*}{.06} \\
\hline & Traditional & 90 & 4.18 & 1.19 & & \\
\hline & Total & 131 & 4.23 & 1.11 & & \\
\hline
\end{tabular}

676

$677 \quad$ Note: $* \mathrm{p}<.05 * * \mathrm{p}<.01$

678

679 
682 Table 4

683 Divergent and integrative thinking creativity scores partial correlations (with age as 684 controlled variable) with the different types of motivations

\begin{tabular}{llllllr}
\hline & & & & & & \multicolumn{2}{c}{ Group } \\
& Am & External & Introjected & Identified & IM & \\
\hline DT & -.16 & -.03 & $-.20^{*}$ & -.07 & -.11 & $\mathrm{n}=131$ \\
IT & $-.23 * *$ & $-.27 * *$ & $-.22 *$ & -.14 & -.10 & Total \\
\hline DT & -.14 & .02 & .14 & .15 & .19 & $\mathrm{n}=41$ \\
IT & -.09 & $-.51 * *$ & $-.50 * *$ & $-.39 *$ & -.12 & Waldorf \\
\hline DT & -.14 & -.05 & $-.32 * *$ & -.15 & -.19 & $\mathrm{n}=90$ \\
IT & $-.29 * *$ & -.11 & -.08 & .01 & -.08 & Traditional \\
\hline Note: $* \mathrm{p}<.05 ; * * \mathrm{p}<.01 ; * * * \mathrm{p}<.001$ & & & &
\end{tabular}

686 
689 Table 5

690 Partial correlations (with age as controlled variable) between divergent or integrative 691 thinking creativity scores and mean well-being score $(n=131)$.

\begin{tabular}{llllr}
\hline & DT & IT & SWLS & Group \\
\hline DT & 1 & & & \\
IT & $.28 * *$ & 1 & & \\
SWLS & -.08 & -.08 & 1 & Total \\
SLSS & .02 & -.01 & $.84 * * *$ & $\mathrm{n}=131$ \\
\hline DT & 1 & & &
\end{tabular}

IT $\quad-.12 \quad 1$

$\begin{array}{lllll}\text { SWLS } & -.20 & -.48 * * & 1 & \text { Waldorf }\end{array}$

\begin{tabular}{lllll} 
SLSS & -.11 & $-.41 * *$ & $.77 * * *$ & $\mathrm{n}=41$ \\
\hline
\end{tabular}

DT 1

IT $\quad .41 * * * \quad 1$

$\begin{array}{llllll}\text { SWLS } & -.04 & .02 & 1 & \text { Traditional }\end{array}$

\begin{tabular}{lllll} 
SLSS & .07 & .07 & $.86 * * *$ & $\mathrm{n}=90$ \\
\hline
\end{tabular}

$692 \quad$ Note: $* \mathrm{p}<.05 ; * * \mathrm{p}<.01 ; * * * \mathrm{p}<.001$

693

694

695

696

697

698

699

700

701

702

703

704

705

706

707

708

709 
712 Figures

713

714 Figure 1: Mean score of Students' Life Satisfaction Scale (SLSS) according to the type of 715 educational method with age as controlled variable (Vertical bars denote 0.95 confidence 716 intervals).

717

718

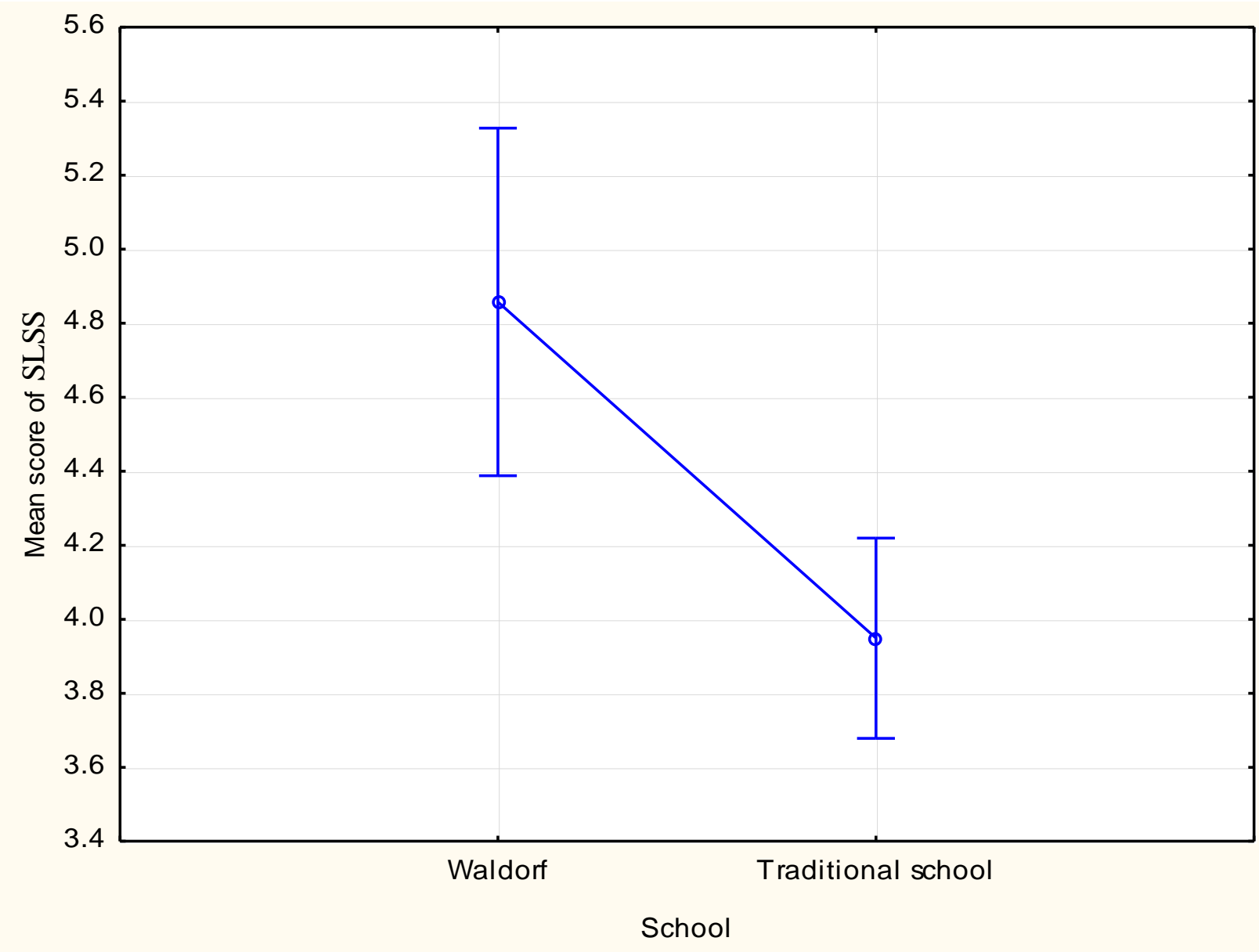


722 Amabile, T. M., Barsade, S. G., Mueller, J. S., \& Staw, B. M. (2005). Affect and Creativity at 723 work. Administrative Science Quarterly, 50(3), 367-403.

724

725 Hirt, E. R., Melton, R. J., McDonald, H. E., \& Harackiewicz, J. M. (1996). Processing goals, 726 task interest, and the mood-performance relationship: A mediational analysis. Journal of 727 Personality and Social Psychology, 71(2), 245-261.

728

729 Examining the gambling behaviors of Chinese online lottery gamblers: Are they rational?

730 Yuan, Jia; Journal of Gambling Studies, Vol 31(2), Jun, 2015 pp. 573-584. Publisher: 731 Springer; [Journal Article]

732 